\title{
The Nursing work and the construction of a democratic society
}

\author{
Lenira Maria Wanderley Santos de Almeida', Regina Maria dos Santos" \\ ' Universidade Federal de Alagoas, School of Nursing and Pharmacy. \\ President of the Brazilian Nursing Association, Alagoas Section, 2013-2016 Term. Maceió, Alagoas, Brazil. \\ "Universidade Federal de Alagoas, School of Nursing and Pharmacy. \\ Director of the Center of Studies and Research in Nursing of the Brazilian Nursing Association, \\ Alagoas Section, 2013-2016 Term. Maceió, Alagoas, Brazil.
}

\begin{abstract}
How to mention this article:
Almeida LMWS, Santos RM. The Nursing work and the construction of a democratic society. Rev Bras Enferm [Internet]. 2017;70(5):896-7. [Thematic Edition "Good practices and fundamentals of Nursing work in the construction of a democratic society"] DOI: http://dx.doi.org/10.1590/0034-7167.2017700501
\end{abstract}

In Brazil, the Nursing work is performed by an expressive contingent of workers, which - according to the last survey by the Brazilian Nursing Association - comprised 1,856,683 professionals, mostly women, distributed into three professional categories: Nurses, Nursing Technicians and Nursing Assistants, who work in public and private health care networks. With salaries lower than other professionals of the sector, they have extensive workdays and shifts (including night shifts), experience authoritarian relationships and constantly have to deal with pain, loss and death of patients, transforming it into a hard work ${ }^{(1)}$.

Aspects such as importance, necessity, stress, laboriousness, achievement, satisfaction, among others that are part of the nature of the work in itself, are also present in the Nursing practice. They are characteristics that arise from the relation between capital and work - relationship between people that hold knowing and doings and perform a specific work mediated by people that have the means for those to perform their production actions and activities.

Brazil is a country organized geopolitically as a Federative Republic, and has capitalism as the current economic model, where the relations between capital and labor occur on the basis of obtaining the greatest profit or accumulation possible. This is the reason one observes a series of innovations in those relations, in order to benefit modalities increasingly favorable to the rise of capital to the detriment of labor and respective workers.

The thematic proposal of the $69^{\text {th }}$ Brazilian Nursing Congress (CBEn in the Portuguese acronym) aims to discuss the type of democracy that exists in Brazil, possible influences on the situation of Brazilian Nursing and the democracy defended by the Brazilian Nursing Association: inclusive, free and fair. The democratic society may be understood as a social and political order that assures to its members equality of social status, and may be exerted in two models: competitive or participative democracy. The former model is proper of industrialized societies, whereas the latter demands an enlightened society, capable of participating collectively in the decision-making process to be concretized by the executive power.

The competitive democracy represents a selection method of political elites capable of making legislative and administrative decisions necessary for the collectivity's welfare. The key features of this democracy are the existence of a competitiveness environment between rival elites and political parties, as well as an independent and well trained body of administrators and constitutional and practical limits of the political decision scope ${ }^{(2)}$. In this type of democracy, the main competition is between the elite members for the VOTE of an electorate poorly informed and/or emotionally oriented, a political culture that incentives the emergence of technically qualified specialists and managers, as well as competition for power and advantages among States in the international system ${ }^{(2)}$.

The participative democracy, such as described by Habermas, justifies the political power exercise based on the public debate between free citizens in equal participation conditions. It defends that the legitimacy of 
political decisions comes from discussion processes that, oriented by inclusion, pluralism, participative equality, autonomy and social justice principles, reorder the logic of traditional political power ${ }^{(3)}$.

In any case, there will only be a real democratic society if social equality is assured by the distributive justice of three sets of rights for all citizens: civil, political and social rights. Social rights, including the right to labor, are those that must assure that all individuals have material conditions considered as vital for the full enjoyment of the other rights, and this is the reason why they are manifested by State intervention on the social order so that to decrease social inequalities, tending to have excessively high cost and occur in the long term. It is the case of health, education and social assistance public policies, for instance.

More specifically, one observes that the Nursing work brings us face to face with the qualification inequality characteristic of a competitive democracy: medium and high education levels, which originate two different functions in the same knowledge field, in which one recognized that this labor division can be seen as technical or intellectual only in the superficial level of the discourse. Internally, it is a social division, once not everybody reaches high education in a country of profound social inequalities.

This difference is one of the elements that difficult the recognition, by these two professional categories, that the work they develop is adequate for a democratic society beyond the competition among elite members, directly to a participative democracy, and this is the defended and desired model, to which the Nursing work may contribute and whose potential may be seen in three dimensions: the first, in the exercise of public health, for the capacity that it has of entering the individual's residence and there developing orientation work to promote and protect health and prevent diseases, what reveals social inequities that have the power to impel the community to organize itself to fight for its rights; the second, for the educative action that may change life perspectives and even oppose the interests of the productive sector in health, by both education in health and formation of new professionals within this critical perspective; and the third, for care actions in illness situations, with all the technical, scientific and technological apparatus that it has accumulated since its constitution as a profession in the $19^{\text {th }}$ Century, when it starts intervening, in an organized manner, on the individual, his/ her family and collectivity.

Due to the social justification that maintains it as essential in the world, Nursing is not, never was and will not be the cure of anyone, but the CARE of people in their context and life circumstances, including in the needs in individual and public health. In this condition, the Nursing work treated as a mere procedure is not capable of participating in the construction of a democratically inclusive society. In order to contribute, the political formation is essential for the Nursing work to fully develop, because the professionals with political consciousness will fight not only for their social rights, but also for the rights of those who they care for.

In this process, technical improvement is necessary and desirable for the comprehension that the act of taking care needs to be updated, decisive, with the greatest benefit and the smallest risk, and research is the main source of improvement when its results impact the daily social practice. In this perspective, the search for better evidences of Nursing care may stop being a competitive strategy to become source of a more adequate Nursing care. The Nursing work should take this path, and here it is possible to say: the citizens users are our greatest and best allies.

The $69^{\text {th }}$ Brazilian Nursing Congress is another achievement of the Brazilian Nursing Association, through the Alagoas Section, with support from all Sections and Regional Units. With the main theme "The Nursing work in the construction of a democratic society", it proposes to provoke broad and profound debates among the participants on the Nursing work in Brazil, especially in a situation of dismantling of labor and social security rights, as well as in the politics and the Brazilian State's public health system - the Brazilian Unified Health System (SUS) -, essential space for full exercise of rights, knowing and doings that are related to us.

\section{REFERENCES}

1. Felli VEA, Baptista PCP. Saúde do Trabalhador de Enfermagem. Barueri, SP: Manole; 2015.

2. Santos RC. A democracia capturada: poder econômico poluidor da democracia brasileira: sistemas de controle. [Dissertação]. Universidade Presbiteriana Mackenzie, São Paulo. 2017[cited 2017 Jan 14];112 f. Available from: http://tede.mackenzie.br/jspui/handle/tede/3121

3. Habermas J. Direito e democracia: entre a facticidade e a validade. Beno Siebeneichler F. (Trad.), V. 2. Rio de Janeiro: Tempo Brasileiro, 1997. 